\title{
Environmental factors and polymorphisms of interleukin genes contribute to susceptibility to chronic periodontal disease
}

\author{
J.A.X. Manso ${ }^{1,2}$, R. Hannum ${ }^{1}$, J.S. Fortes ${ }^{1}$, S.S.M. Duarte ${ }^{1,3}$, \\ A.S. da Cruz ${ }^{1}$, L.B. Minasi ${ }^{1}$, A.D. da Cruz ${ }^{1,2,3,4}$ and C.C. da Silva ${ }^{1,2,4}$ \\ ${ }^{1}$ Núcleo de Pesquisas Replicon, Escola de Ciências Agrárias e Biológicas, \\ Mestrado em Genética, Pontifícia Universidade Católica de Goiás, GO, \\ Goiás, Brasil \\ ${ }^{2}$ Programa de Pós-Graduação em Biotecnologia e Biodiversidade, nível \\ doutorado, Universidade Federal de Goiás, GO, Goiás, Brasil \\ ${ }^{3}$ Programa de Pós-Graduação em Genética e Biologia Molecular, \\ Universidade Federal de Goiás, GO, Goiás, Brasil \\ ${ }^{4}$ LaGene-Laboratório de Genética Humana e Biologia Molecular, \\ Laboratório Estadual de Saúde Pública Dr. Giovanni Cysneiros, Secretaria \\ Estadual de Saúde de Goiás, GO, Goiás, Brasil
}

Corresponding author: J.A.X. Manso

E-mail: joao.xm@hotmail.com

Genet. Mol. Res. 19 (3): gmr18568

Received March 16, 2020

Accepted August 31, 2020

Published September 30, 2020

DOI http://dx.doi.org/10.4238/gmr18568

\begin{abstract}
Chronic periodontal disease (CPD) is described as a recurrent inflammatory condition of tooth supporting tissues, caused by bacterial infections and self-destructive processes of immune activity mediated by pro-inflammatory cytokines, of which the interleukins $1 \beta, 6$ and 8 stand out; together with other biomolecules these cytokines mediate innate immunity. These molecules may have variations in their genes, such as single nucleotide polymorphisms, which together with environmental factors, can affect susceptibility to this disease condition. We investigated how polymorphisms of the $I L 1 B$, IL6 and CXCL8 genes, as well as sociodemographic and lifestyle aspects, affect susceptibility to chronic periodontal disease in a group of volunteers in Goiânia city. Peripheral blood samples from 152 volunteers were obtained via venipuncture and grouped into controls and a case group (CPD), according to the result of the
\end{abstract}


periogram, previously elaborated, together with a questionnaire concerning habits and life style. The DNA of the samples was genotyped using PCR-RFLP and qPCR, for each molecular marker. A significant trend to develop CPD was detected for individuals who brush their teeth less than twice a day. The allele of minor frequency of the variants rs1143634, rs1800796, and rs2227539 were associated with $C P D$, revealing a significant predictive effect $(\mathrm{P}<0.05)$. The most significant findings involved the $\mathrm{T}$ (rs1143634) and $\mathrm{C}$ (rs1800796) alleles, which were associated with increased risk, when examined individually and together. We concluded that this is a multifactorial disease, although the genetic influence was predominant.

Key words: Interleukin; Genetic polymorphism; Periodontitis; Chronic diseases

\section{INTRODUCTION}

Hereditary factors that could affect periodontal diseases (PD) have been researched for decades, after it became clear that both genetic and environmental factors affect susceptibility. It is assumed that a number of these factors are related to the cause and progression of this condition (Michalowicz, 1994). Chronic periodontal disease (CPD) consists of recurrent and progressive inflammation of the tooth supporting tissues; it has high prevalence and is the second most common pathological dental condition worldwide (Almeida et al., 2006). It is caused initially by bacterial infections (gram-negative) that, clinically present as gingival inflammation, bleeding on probing, periodontal pockets, and loss of gingival insertion and alveolar bone (Flemmig, 1999).

During infection, immunological mediators lead to inflammatory processes resulting from the bacterial ecological imbalance, which is detected through the products of the gram-negative microorganisms, such as lipopolysaccharides (LPS). These are found in the biofilm and induce the release of pro-inflammatory cytokines, inclduing interleukin $1 \beta$ (IL-1 $\beta$ ), interleukin 6 (IL-6), interleukin 8 (IL- 8), and tumor necrosis factor $\alpha$ (TNF(Hajishengallis, 2015).

Many cytokines have been analyzed to determine their role in genetic susceptibility to complex diseases, including CPD, with special interest in IL-1 $\beta$, IL-6, and IL-8. These inflammatory mediators contribute to the recruitment of defense cells and proteolytic activity, which occurs in the absence of regulatory enzyme inhibitors, due to a homeostatic imbalance, resulting in tissue degradation by proteolytic enzymes (Song et al., 2019).

Polymorphisms of cytokine genes have been linked to the susceptibility to CPD. They can result in changes in the patterns of gene regulation and the function of their proteins, which can influence chronic inflammation and destruction of the tissues that support the teeth (Baker and Roopenian, 2002; Wu et al., 2015). Therefore, evaluated how single nucleotide polymorphisms (SNPs) of the ILIB (rs1143634), IL6 (rs1800795, rs1800796), and CXCL8 (rs4073, rs2227306 and rs2227539) genes, sociodemographic data and life style habits affect susceptibility to CPD disease in a sample of volunteers from Goiânia, Brazil. 


\section{MATERIAL AND METHODS}

This a case-control study carried out in the Núcleo de Pesquisas Replicon (NPR), at the Escola de Ciências Agrárias e Biológicas of the Pontifícia Universidade Católica de Goiás (PUC Goiás) and in the Laboratório de Mutagênese (LABMUT) at the Universidade Federal de Goiás (UFG). This study was approved by the Ethics and Research Committee of the PUC Goiás (Protocol $\mathrm{n}^{\circ}$ : 201210267001140), and the participants that took part in this investigation voluntarily signed a free and informed consent form.

\section{Description of the Sample}

The sampling was non-probabilistic, consisting of convenience samples from 51 individuals with CPD and 101 healthy individuals (Controls), all residing in the municipality of Goiânia, Brazil. Participants who volunteered were classified according to gender, age, alcohol consumption, and oral hygiene, considering under 18 and smoking as exclusion criteria.

The exclusion of smoking individuals was included in order to help in the analysis, as it is a characteristic that increases the risk of this disease (Lertpimonchai et al., 2017). The evaluation of the genetic aspects involved in CPD was the main scope of this study, and therefore the aforementioned environmental factor was excluded. However, there are limitations to exclude all the environmental factors, since the restriction of alcohol consumption, for instance, is unlikely to occur.

\section{Clinical Examination (Periodontal Exam)}

The volunteers in this study were submitted to a clinical examination called a periogram, which was carried out by an odontologist specialized in periodontics. During the exam, a millimeter periodontal probe (similar to the 621 model of the WHO) and oral mirrors were used, adopting the community periodontal index (CPI) model (Brasil. Ministério da Saúde. Secretaria de Políticas de Saúde, 2001) as a diagnostic parameter.

\section{DNA Genomic Isolation}

The biological samples were obtained through the collection of $4 \mathrm{~mL}$ of peripheral blood in tubes containing ethylenediaminetetraacetic acid (EDTA), taken by a qualified professional. The DNA was extracted from the whole blood using the Ilustra Blood Genomic Mini Spin ${ }^{\circledR}$ (GE healthcare, UK) and AxyPrep Blood Genomic PrepTM (Axygen Biosciences, USA) kits, according to the guidelines of the manufacturers.

\section{Genotyping of rs1143634 (+3954 C > T)}

The extracted DNA was submitted to PCR reaction, yielding products that were fragmented by the RFLP method. The primer sequences used in the PCR and the restriction fragments obtained in the RFLP are shown in Table 1.

The PCR reactions occurred under the following conditions: PCR buffer $(10 \mathrm{mM}$ Tris-HCl [pH 8.8], $1.5 \mathrm{mM} \mathrm{MgCl}_{2}, 50 \mathrm{mM} \mathrm{KCl} 2,0.1 \%$ Triton X-100); $1 \mathrm{mM} \mathrm{MgCl} 2 ; 0.2$ $\mathrm{mM}$ of dNTPs; $2.0 \mathrm{U}$ of Taq DNA polimerase and $2 \mathrm{M}$ of primers. The PCR thermocycling conditions were an early denaturation cycle at $95^{\circ} \mathrm{C}$ for $5 \mathrm{~min}, 35$ denaturation cycles at 
$94^{\circ} \mathrm{C}$ for $30 \mathrm{~s}$, hybridization at $55^{\circ} \mathrm{C}$ for $30 \mathrm{~s}$, extension at $72^{\circ} \mathrm{C}$ for $30 \mathrm{~s}$, and a final extension at $72^{\circ} \mathrm{C}$ for $5 \mathrm{~min}$.

Table 1. Sequences of the primer oligonucleotides (primers) and the restriction fragments related to the amplicon of $194 \mathrm{pb}$ containing the SNP rs 1143634 of the IL1B gene.

\begin{tabular}{lll}
\hline $\boldsymbol{I L 1 B}$ & Sequence $\left(\mathbf{5}^{\prime} \rightarrow \mathbf{3}^{\prime}\right)$ & Fragments \\
\hline \multirow{2}{*}{ Primers rs1143634 } & 5'-CTCAGGTGTCCTCGAAGAAATCAAA-3 & 194bp \\
\hline \multirow{2}{*}{ RFLP } & 5'-GCTTTTTGCTGTGAGTCCCG-3' & $97,85,12 \mathrm{bp}$ \\
& Allele 1 TCGA & $182,12 \mathrm{bp}$ \\
\hline
\end{tabular}

The products of the reaction were separated in a constant electric field of $10 \mathrm{~V} / \mathrm{cm}$ in a $1.5 \%$ agarose gel in Tri-Boric-Acid-EDTA (TBE). The DNA was visualized by staining the agarose gel (Figure 1) in an ethidium bromide solution at $5 \mu \mathrm{g} / \mathrm{mL}$. The images were obtained by the Gel Doc XR+ Gel Documentation System (BioRad, USA).

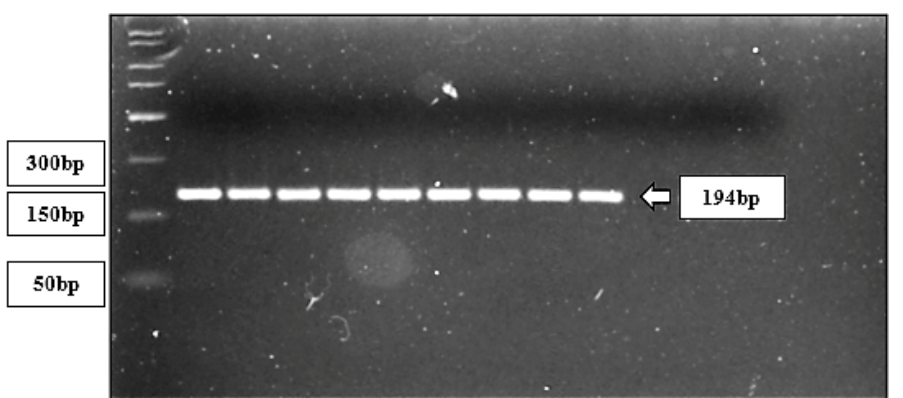

Figure 1. Agarose gel 1.5\%, stained with ethidium bromide, showing the PCR products of $194 \mathrm{bp}$.

The PCR products were subjected to a RFLP reaction, being treated with the TaqI ${ }^{\circledR}$ (Invitrogen, EUA) enzyme at $65^{\circ} \mathrm{C}$ for $1 \mathrm{~h}$, for enzymatic digestion. Later, the fragments of $12 b p+85 b p+97 b p$ (allele 1) and 12bp $+182 b p$ (allele 2) were obtained by electrophoretic separation in polyacrylamide gel $8 \%$ and then stained with $0.1 \%$ silver nitrate (Figure 2 ).

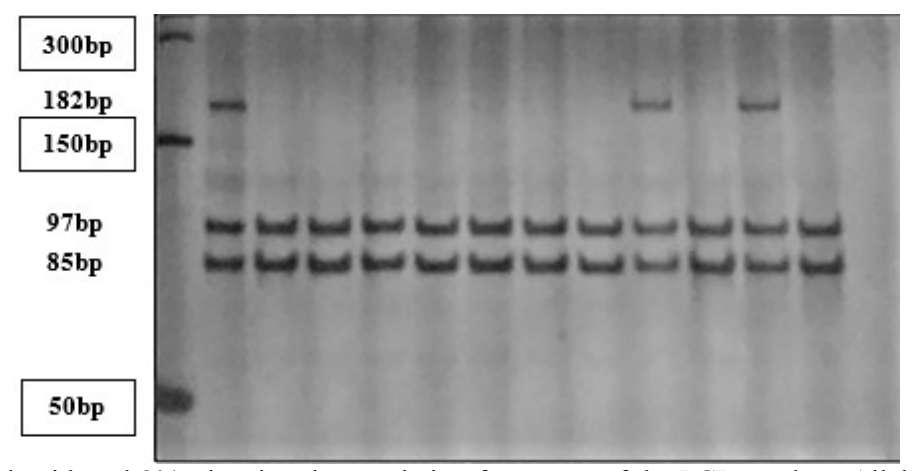

Figure 2. Polyacrylamide gel $8 \%$, showing the restriction fragments of the PCR product. Allele $1(\mathrm{~A} 1)=12 \mathrm{bp}+$ $85 \mathrm{bp}+97 \mathrm{bp}$ and allele $2(\mathrm{~A} 2)=12 \mathrm{bp}+182 \mathrm{bp}$, corresponding to $\mathrm{C}$ and $\mathrm{T}$, respectively. The fragment of $12 \mathrm{bp}$ was not detected by this methodology. 


\section{Genotyping of the rs1800795, rs1800796, rs4073, rs2227306, and rs2227539 SNPs}

The genotyping of the rs1800795, rs1800796, rs4073, rs2227306, and rs2227539 SNPs was performed using the real time quantitative PCR (qPCR) method, employing the TaqMan probes and Master Mix (Thermo Fisher Scientific, Massachusetts, EUA). Figure 3 shows an example of allele discrimination with VIC and FAM marking through genotyping performed in an Applied Biosystems StepOnePlus ${ }^{\text {TM }}$ Real Time PCR Systems thermal cycler (Applied Biosystems, USA).

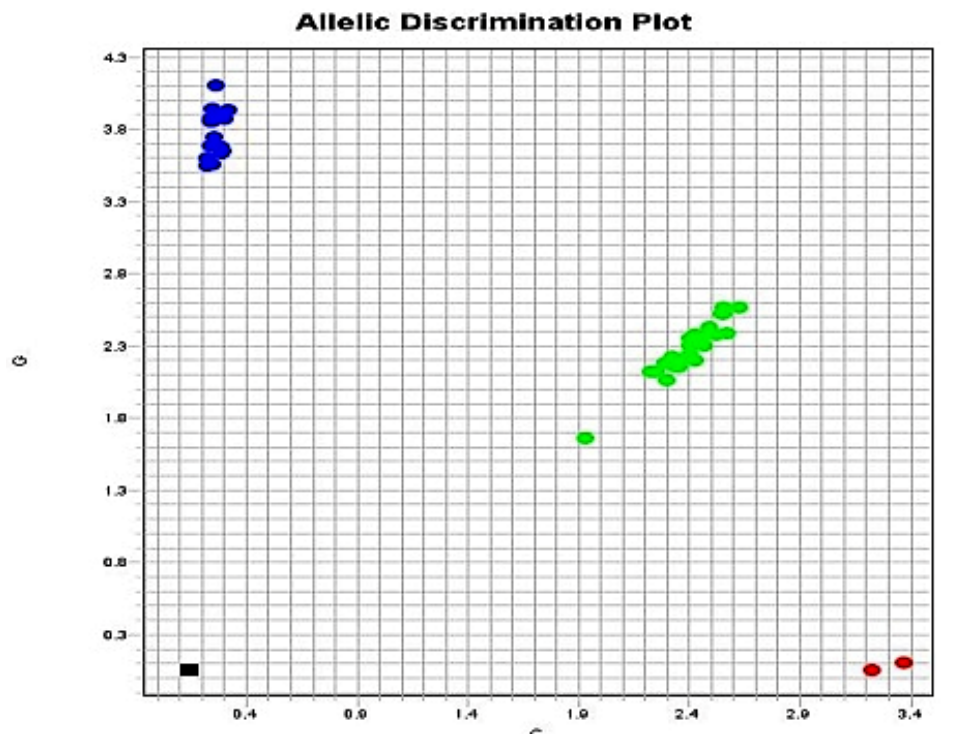

Figure 3. Graphic representation of the distribution of the genotypes of the rs 1800795 SNP of the IL6 gene after the $\mathrm{qPCR}$ reaction. Legend: Red balls $=$ Homozygotes for cytosine; Green balls= Heterozygotes guanine/cytosine; Blue balls $=$ Homozygotes for guanines; Black Square= Negative control.

The reaction parameters were pre-established by the manufacturers using the Custom TaqMan ${ }^{\circledR}$ SNP Genotyping Assay (Applied BiosytemTM) handbook, consisting of an early denaturation at $95^{\circ} \mathrm{C}$ for $10 \mathrm{~min}$, followed by 40 cycles at $95^{\circ} \mathrm{C}$ for $15 \mathrm{~s}$ and $1 \mathrm{~min}$ at $60^{\circ} \mathrm{C}$ for hybridization and extension, using the components presented in Table 2. Genotyping occurred by analyzing the fluorescence standard of each sample, as shown in Figure 3.

Table 2. Components of the qPCR reaction, volume, and final concentration of the mixture.

\begin{tabular}{lll}
\hline Components & Volume & Final Concentration \\
\hline TaqMan Master Mix & $5.0 \mu \mathrm{L}$ & $1 \mathrm{X}$ \\
SNP Genotyping Assay & $0.5 \mu \mathrm{L}$ & $10 \mathrm{X}$ \\
H2O Milli-Q & $3.5 \mu \mathrm{L}$ & $\mathrm{NA}$ \\
DNA Sample & $1.0 \mu \mathrm{L}$ & $20 \mathrm{ng} / \mu \mathrm{L}$ \\
\hline Final Volume & $10 \mu \mathrm{L}$ & \\
\hline
\end{tabular}


The oligonucleotide sequences (probes) marked with fluorophores for the qPCR reactions are shown in Table 03 . It should be noted that all probes were built in the $5^{\prime} \rightarrow 3^{\prime}$ direction.

Table 3. List of the probes used for the qPCR analyses.

\begin{tabular}{|c|c|c|}
\hline Gene & SNP & Context sequence $\left[\right.$ VIC $^{(B)} /$ FAM $\left.^{(B)}\right]$ \\
\hline IL6 & rs 1800795 & ACTTTTCCCCCTAGTTGTGTCTTGC[C/G]ATGCTAAAGGACGTCACATTGCACA \\
\hline IL6 & rs 1800796 & ATGGCCAGGCAGTTCTACAACAGCC[C/G]CTCACAGGGAGAGCCAGAACACAGA \\
\hline CXCL8 & rs4073 & TTATCTAGAAATAAAAAAGCATACA[A/T]TTGATAATTCACCAAATTGTGGAGC \\
\hline CXCL8 & rs 2227306 & AACTCTAACTCTTTATATAGGAAGT[C/T]GTTCAATGTTGTCAGTTATGACTGT \\
\hline CXCL8 & rs 2227539 & ATCTTAGCAGTCAATTAATGTTAAA[A/T]TGAAGATTTAGAAAAAACTATATAT \\
\hline
\end{tabular}

\section{Data Analyses}

The data obtained were organized in the Microsoft Office Excel software (2016) and statistical tests were done using IBM SPSS ${ }^{\circledR}$ software, version 21.0.0 (IBM Corporation, USA), and BioEstat, version 5.3. The analyses were performed assuming a $95 \%$ confidence interval (CI) and a level of significance $\leq 0.05$, using non-parametric tests due to the profile of variables.

The distribution of the genetic and socio-demographic data in the studied groups was inferred using the Chi-square test. According to the SNP database (NCBI), genotypes containing the allele of minor frequency had their frequencies analyzed together, assuming the mutant allele as a risk factor (adjusted genotype).

Probability testing and odds ratio (OR) analysis were performed when required. Binary Logistic Regression were employed in order to obtain equation models that explained the association of the genotypes with the disease, inferring the prediction of the tested variables. The Hardy-Weinberg Equilibrium (HWE) was also calculated by evaluating the gene balance of the studied groups.

\section{RESULTS}

\section{Socio-demographic and Clinical Parameters}

The clinical and socio-demographic data obtained are shown in Table 4, which presents the frequencies and distributions of the variables between the controls and individuals with CPD. The clinical parameter described the level of insertion loss and the clinical stage of the disease.

The results revealed the lack of association of the variables gender, age, alcohol consumption, and flossing with the CPD casuistry. Significant differences were observed when it came to the distribution of brushing frequencies $(P=0.04)$, with a significant tendency $(\mathrm{P}=0.01)$ to present the disease in individuals who brush their teeth less than twice a day. 
Table 4. Quantified values of sociodemographic variables, lifestyle and clinical aspects between the groups studied and their respective $\mathrm{P}$ values (when applicable), according to the chi-square test (d) and the propensity test (e).

\begin{tabular}{|c|c|c|c|c|}
\hline Variables & Category & $\begin{array}{l}\text { Groups } \\
\text { Controls }(n=101)\end{array}$ & $\operatorname{CPD}(n=51)$ & $P$ value \\
\hline \multirow{2}{*}{ Gender } & Male & $46.5 \%$ & $45.1 \%$ & \multirow{3}{*}{$1.0^{\mathrm{d}}$} \\
\hline & Female & $53.5 \%$ & $54.9 \%$ & \\
\hline \multirow{4}{*}{ Age } & $<20$ & $19.8 \%$ & $27.5 \%$ & \\
\hline & $20-30$ & $50.5 \%$ & $43.1 \%$ & \multirow{3}{*}{$0.5^{\mathrm{d}}$} \\
\hline & $31-40$ & $10.9 \%$ & $15.7 \%$ & \\
\hline & $>41$ & $18.8 \%$ & $13.7 \%$ & \\
\hline \multirow{2}{*}{ Alcohol ingestion } & Ingestion & $61.4 \%$ & $52.9 \%$ & \multirow{2}{*}{$0.4^{\mathrm{d}}$} \\
\hline & No ingestion & $38.6 \%$ & $47.1 \%$ & \\
\hline \multirow{2}{*}{ Use of Dental Floss } & Yes & $82.7 \%$ & $65.2 \%$ & \multirow{2}{*}{$0.08^{\mathrm{d}}$} \\
\hline & No & $17.3 \%$ & $34.8 \%$ & \\
\hline \multirow{2}{*}{ Brushing Frequency } & 1x/day & $1.4 \%$ & $14.3 \%$ & $0.04^{\mathrm{d}}$ \\
\hline & $\geq 2 \mathrm{x} /$ day & $98.6 \%$ & $85.7 \%$ & $0.01^{\mathrm{e}}$ \\
\hline \multirow{3}{*}{$\begin{array}{l}\text { Clinical Level of Insertion Loss } \\
\text { (Probing Depth) }\end{array}$} & $1-2 \mathrm{~mm}(4 \mathrm{~mm})^{\mathrm{a}}$ & - & $51.0 \%$ & - \\
\hline & $3-4 \mathrm{~mm}(5 \mathrm{~mm})^{\mathrm{b}}$ & - & $39.2 \%$ & - \\
\hline & $\geq 5 \mathrm{~mm}(6 \mathrm{~mm})^{\mathrm{c}}$ & - & $9.8 \%$ & - \\
\hline
\end{tabular}

dental floss and brushing frequency; e: $\mathrm{P}$ value $\left(x^{2}\right)$ of the proportion test, used in the brushing frequency variable.

\section{Analyses of the Genetic Data}

Not all the frequencies of the polymorphic genes were consistent with the HardyWeinberg Equilibrium hypothesis. Table 5 presents the results of the analysis, highlighting the rs1143634 (IL1B), rs1800796 (ILO), rs4073 (CXCL8), and 2227539 (CXCL8) genes, which presented constant allelic frequencies compared to the controls.

Table 5. $\mathrm{P}$ values for Hardy-Weinberg analysis of chronic periodontal disease (CPD) propensity according to the risk alleles using the Chi-square test.

\begin{tabular}{ccccccc}
\hline Group & rs1143634 & rs1800795 & $\begin{array}{c}\text { P values } \\
\text { rs1800796 }\end{array}$ & rs4073 & rs2227306 & rs2227539 \\
\hline Controls & 0.06 & $0.05^{*}$ & 0.06 & 1.00 & $<0.05^{*}$ & 0.60 \\
CPD & 0.73 & $<0.05^{*}$ & $<0.05^{*}$ & 0.40 & $<0.05^{*}$ & 0.18 \\
\hline
\end{tabular}

*: significant $\mathrm{P}$ value $(\leq 0.05) \mathrm{c}$

Significant differences $(\mathrm{P}<0.05)$ were detected in the genotype distribution (adjusted genotype) among the studies groups, considering the polymorphisms: rs1143634 (IL1B), rs1800796 (ILO), and rs2227539 (CXCL8). No statistically significant values were found for the other genetic variants tested. The data from the genotypic frequencies and inferential analysis are found in Table 6.

The Binary Logistic Regression analysis detected significant coefficients of $80 \%$ for the $\mathrm{T}$ allele (rs1143634), 70\% for $\mathrm{C}$ (rs1800796) and 80\% for A (rs2227539) in the prediction for the disease. The odds ratio estimate demonstrated significant values for the SNPs rs1143634 and rs1800796. We detected for each $\mathrm{T}$ allele (rs1143634) and $\mathrm{C}$ (rs1800796), when present in their respective loci, an increase of the risk for CPD of 2.1 
times, with confidence intervals of 1.1-4.3 and 1.1-4.1, respectively. The A allele (rs2227539) also showed a 2.1-fold increase in the risk for CPD, but it was not significant $(\mathrm{CI}=1.0-4.5)$.

Table 6. Genotypic frequency (in percent) according to the risk allele and p value obtained in the distribution analysis (Chi-square) between the control and chronic periodontal disease (CPD) groups.

\begin{tabular}{lllll}
\hline SNP & Genotype & $\begin{array}{l}\text { Groups } \\
\text { Controls } \\
\text { (n=101) }\end{array}$ & $\begin{array}{l}\text { CPD } \\
\text { (n=51) }\end{array}$ & P \\
\hline rs1143634 & CC & 67.3 & 49.0 & $0.03^{*}$ \\
& CT/TT & 32.7 & 51.0 & 0.11 \\
rs1800795 & GG & 38.6 & 25.5 & $0.03 *$ \\
& GC/CC & 61.4 & 74.5 & 0.26 \\
rs1800796 & GG & 54.4 & 41.2 & 0.27 \\
& GC/CC & 40.6 & 58.8 & \\
rs 4073 & GA & 24.8 & 33.3 & $0.04 *$ \\
rs2227306 & GT/TT & 75.2 & 66.7 & \\
rs2227539 & CC & 52.5 & 56.1 & 62.7 \\
& CT/TT & 47.5 & 37.3 & \\
\hline
\end{tabular}

*: significant P value ( $\leq 0.05)$; SNP: single nucleotide polymorphism; CPD: chronic periodontal disease.

Additionally, the Binary Logistic Regression model, which combines two independent variables (interaction of factors), was used for the polymorphisms rs 1143634 and rs1800796, due to the increase in risk, previously detected for both. The results were significant $(\mathrm{P}<0.05)$ with a regression coefficient of 1.2 and an odds ratio of $3.4(\mathrm{CI}=1.4$ 8.4), which in turn indicates the effect additive of the mentioned variables, when combined, in increasing the prediction and risk for CPD. Tables 7 and 8 show the results of the Logistic Regression and odds ratio analyzes.

Table 7. Results of the Binary Logistic Regression analysis, where the groups were calculated according to the adjusted genotypes (SNPs). The analysis includes the calculation of the odds ratio.

\begin{tabular}{|c|c|c|c|c|c|c|c|}
\hline SNP & Genotype & $\begin{array}{l}\text { Groups } \\
\text { Controls } \\
(n=101)\end{array}$ & $\begin{array}{l}\text { CPD } \\
(n=51)\end{array}$ & B & $\mathbf{P}$ & $\operatorname{Exp}(B)$ & CI 95\% \\
\hline rs1143634 & $\begin{array}{l}\mathrm{CC} \\
\mathrm{CT} / \mathrm{TT}\end{array}$ & $\begin{array}{l}67.3 \% \\
32.7 \%\end{array}$ & $\begin{array}{l}49.0 \% \\
51.0 \%\end{array}$ & 0,8 & $0.03 *$ & 2.1 & $1.1-4.3^{*}$ \\
\hline rs1800795 & $\begin{array}{l}\mathrm{GG} \\
\mathrm{GC} / \mathrm{CC}\end{array}$ & $\begin{array}{l}38.6 \% \\
61.4 \%\end{array}$ & $\begin{array}{l}25.5 \% \\
74.5 \%\end{array}$ & 0,6 & 0.11 & 1.8 & $0.9-3.9$ \\
\hline rs1800796 & $\begin{array}{l}\mathrm{GG} \\
\mathrm{GC} / \mathrm{CC}\end{array}$ & $\begin{array}{l}54.4 \% \\
40.6 \%\end{array}$ & $\begin{array}{l}41.2 \% \\
58.8 \%\end{array}$ & 0,7 & $0.03 *$ & 2.1 & $1.1-4.1^{*}$ \\
\hline rs 4073 & $\begin{array}{l}\mathrm{AA} \\
\mathrm{AT} / \mathrm{TT}\end{array}$ & $\begin{array}{l}24.8 \% \\
75.2 \%\end{array}$ & $\begin{array}{l}33.3 \% \\
66.7 \%\end{array}$ & $-4,0$ & 0.27 & 0.7 & $0.3-1.4$ \\
\hline rs2227306 & $\begin{array}{l}\mathrm{CC} \\
\mathrm{CT} / \mathrm{TT}\end{array}$ & $\begin{array}{l}52.5 \% \\
47.5 \%\end{array}$ & $\begin{array}{l}43.1 \% \\
56.9 \%\end{array}$ & 0,4 & 0.28 & 1.5 & $0.7-2.9$ \\
\hline rs2227539 & $\begin{array}{l}\text { TT } \\
\text { TA/AA }\end{array}$ & $\begin{array}{l}78.2 \% \\
21.8 \%\end{array}$ & $\begin{array}{l}62.7 \% \\
37.3 \%\end{array}$ & 0,8 & $0.04 *$ & 2.1 & $1.0-4.5$ \\
\hline
\end{tabular}

*: significant $\mathrm{P}$ value $(\leq 0.05)$; SNP: single nucleotide polymorphism; CPD: chronic periodontal disease; B: Coefficient regression; P: probability value; $\operatorname{Exp}(\mathrm{B})$ : Exponential of the Regression coefficient or odds ratio; CI: Confidence Interval. 
Table 8. Results of the Binary Logistic Regression analysis (interaction factors), where the groups were analyzed according to the SNPs rs 1143634 and rs 1800796 combined.

\begin{tabular}{|c|c|c|c|c|}
\hline SNPs & B & $\mathbf{P}$ & $\operatorname{Exp}(B)$ & CI 95\% \\
\hline $\begin{array}{l}\text { rs1143634 and } \\
\text { rs1800796 }\end{array}$ & 1.2 & $0.01 *$ & 3.4 & $1.4-8.4^{*}$ \\
\hline
\end{tabular}

\section{DISCUSSION}

The impact of environmental factors on the propensity for CPD is widely recognized. Aspects such as oral hygiene conditions (bacterial plaque), smoking, stress, and systemic factors can intensify the inflammatory condition of the disease (Stabholz et al., 2010).

The widespread view in the scientific community recognizes the relevant role of oral hygiene for CPD prevention, with the bacterial plaque resulting from limited and infrequent oral hygiene (Devji, 2017). It is noteworthy that plaque levels have been related to the propensity to the disease, although this does not apply in a restricted way to all types of periodontitis (Stabholz et al., 2010).

In the present study, the oral hygiene parameters used were categorical, so that the rates of brushing frequency and flossing were evaluated, obtaining results that corroborated the current scientific thought, since infrequent brushing was statistically associated with CPD, according the study of Lertpimonchai et al. (2017), which reported the statistical association of CPD with lack of adequate buccal hygiene, the risk being from two to five times higher.

Regarding the analyses of the genetic factors, the results showed the involvement of polymorphisms in the CPD casuistry, so that the lowest frequency alleles of the rs1143634 (IL1B), rs1800796 (IL6), and 2227539 (CXCL8) variants were significantly more prevalent in the group composed of sick individuals.

The IL-1 $\beta(I L 1 B)$ is a pro-inflammatory mediator inducing the expression of IL-6 and IL-8 genes, in addition to other immunological mediators that, in recurrent inflammation, contribute to the destruction of the connective matrix of the tooth supporting tissues and bone resorption (Song et al., 2019). Higher concentrations of IL-1 $\beta$ in the salivary fluid have been quantified in individuals with CPD, showing the increase according to the level of severity of the disease (Sánchez et al., 2013), in addition to high rates of ILIB transcripts in patients with CPD and chronic kidney disease (Braosi et al., 2012). Additionally, Gore et al. (1998) reported the association of the T allele with the level of disease severity, showing cohesion with the findings of Pociot et al. (1992), who reported an increased secretion of IL- $1 \beta$ associated with the T allele of the rs1143634 polymorphism in an in vitro analysis, observing an allele-dosage effect, so that heterozygotes (CT) produced more IL-1 $\beta$ than wild homozygotes (CC) and less than mutant homozygotes (TT).

In this study, genotypes containing the $\mathrm{T}$ allele (rs1143634) were associated with susceptibility to CPD, so that the increased risk and the predictive effect were observed for the disease. This is in accordance with the work of Moreira and collaborators (2005), who analyzed a Brazilian population in the state of Minas Gerais, suggesting that this allele is a risk factor for CPD. In the study by Ribeiro et al. (2016), also in a Brazilian population, the 
increased risk for $\mathrm{CPD}$ associated with the $\mathrm{T}$ allele was again reported, so that other variables (smoking and sex), when combined with the said allele, changed the risk to higher values.

Other studies evaluated the susceptibility to CPD under the effect of the T allele (rs1143634), as in the study by López et al. (2009), who reported the significant association of the CT and TT genotypes in a Chilean population, as well as Majumder and collaborators (2019) in an Indian population, demonstrating a high frequency of the T allele in individuals with CPD. However, there are also reports of no association of the $\mathrm{T}$ allele with this disease (Trevilatto et al., 2011; Setty et al., 2018).

Seeking a greater understanding, alternative approaches have gained notoriety, such as the work conducted by Yin and collaborators (2016), who opted for a meta-analysis study using data available in the literature between 2008 and 2014. This study assessed the heterogeneity between publications, referring to the frequencies of alleles and genotypes, obtaining a significant association of the T allele (rs1 143634) with the CPD, increasing risk by 1.5 times more for the developing the condition. In a similar way, the work of Da Silva and collaborators (2018) has also opted for a meta-analysis approach, which included data among 1998 to 2016, reporting the increase in the risk by 1.4 times more for CPD due to the presence of the $\mathrm{T}$ allele, admitting it as a risk factor. The study has also included a stratified approach, showing a significant relationship of this allele with Caucasian, Asian, and mixed populations.

Regarding the consequences, it is understood that the Allele T (rs1143634) may interfere with the performance of IL-1 $\beta$, although the implications for the pathogenesis of CPD are not yet understood. Different polymorphisms of interleukin 1 have been studied in terms of susceptibility to periodontitis under genetic influence. The first analyzes involved a wider range of non-functional variants (Laine et al., 2012), although the influence of polymorphisms in the promoter region with the severity of the condition (CPD) in different ethnic groups was later reported (Wu et al., 2015). Loos et a. (2005) comment that, during the first researches with variants of the $I L 1 B$ and TNFA genes, it was proposed that the genetic polymorphisms increase the expression of their respective proteins, contributing to chronic inflammation in periodontitis. However, it is known that according to the SNP database (NCBI, 2020), that rs1143634 represents a genetic variant of synonymous coding. However, it is reported that synonymous polymorphisms can cause inactivation of the native donor splicing site, resulting in an early stop codon or a leap from the exon, resulting in a shorter mRNA and consequently a truncated protein, which is likely to be degraded or functionally inactive (Thi Tran et al., 2005; Bellone et al., 2006; Katneni et al., 2019).

Also participating in the inflammatory processes, the IL-6 is characterized as a pleiotropic mediator found in large concentrations in the gingival crevicular fluid (Noh et al., 2013) in order to stimulate osteoclastic bone resorption (Wu et al., 2017). The increased risk and susceptibility to inflammatory diseases, conditioned by variants of the IL6 promoting region (Barartabar et al., 2018) is reported, suggesting the participation of SNPs in the progression of the disease (Xiao et al., 2009), collaborating in the chronic inflammatory condition.

Among the polymorphisms, the rs 1800796 has been related to periodontal conditions, recognizing the $\mathrm{G}$ allele as a possible risk factor, representing a recessive genetic model in the participation of the pathogenesis (Shao et al., 2009; Shi, 2017). These findings contrast with those presented in this study, which quantified a significantly higher 
rate of genotypes containing the $\mathrm{C}$ allele in the group of sick individuals, conditioning a risk increased, estimating a $70 \%$ prediction for the disease (CPD).

Xiao and collaborators (2009) stressed that there is still not sufficient evidence to attribute the $\mathrm{C}$ allele (rs1800796) a protective role, since its frequency was not significantly different among the groups in a survey conducted with Chinese, including individuals with CPD. Similar results were obtained in other surveys with populations in Asia and Europe, evaluating the association of rs 1800796 with CPD (Zhang et al., 2014; Chatzopoulos et al., 2018). Also noteworthy, is the analysis of Ferrari and collaborators (2003), who detected increased IL-6 activity in vitro, conditioned by the C allele (rs 1800796), resulting in the increase of the C-reactive protein level, which is a marker of bone resorption, suggesting the variant is related to chronic diseases.

Finally yet importantly, the IL-8 chemokine plays a pro-inflammatory chemotherapeutic role in recruiting leukocytes and inflammatory cells to the sites of inflammation, taking part in the autoimmune conditions, which include those with a chronic nature. The effect of chemokines on the connective tissue damage has been observed in chronic inflammatory conditions through the increase of the tissue concentration levels of the IL-8 protein (Santos et al., 2012).

The increase in the IL-8 levels has also been reported in the gum tissues during the progression of CPD (Finoti et al., 2017), assuming the potentiation of the inflammatory processes and tissue destruction (Paul et al., 2012). It is acknowledged, therefore, that genetic polymorphisms in regulatory regions would imply increased production and activity of protein products.

The CXCL8 gene polymorphisms have been related to susceptibility to chronic and inflammatory conditions involving eastern and western populations (Cui et al., 2016; Bishu et al., 2018). The rs4073 is one of the most analyzed SNPs regarding periodontal disease susceptibility, reporting associations with inflammatory conditions (Zhang et al., 2014; Kaur et al., 2019), although this has not been found in the present study.

On the other hand, rs2227539 is an intronic variant of the CXCL8 gene poorly addressed in research that evaluate disease-responsible genes. In the present study, genotypes with A allele (rs2227539) was shown to be associated to CPD, showing a significant prevalence in sick individuals, with an $80 \%$ prediction for this disease, although the increase in risk was not statistically significant. It is believed that the absence of the AA genotype, in the studied groups, influenced the no significance of the results, in terms of the increase in risk, since each A allele could have an additive effect on the chance for CPD. The findings obtained allow a parallel with the findings of studies involving other genes and polymorphisms, which reported the interference of intronic variants in the regulation of transcripts, observing implications on homeostasis in pathological conditions, as well as on the metabolism of exogenous substances (Wang et al., 2011; Qaddourah et al., 2014).

It is believed that high levels of IL-8 are related to tissue damage (Finoti et al., 2017), promoting a disproportionate recruitment of neutrophils and increased production of interleukin 17, which acts on osteoblasts by stimulating the RANKL expression, which is an important osteoclastogenesis factor (Rosales and Querol, 2017), resulting in bone resorption and tissue destruction.

In summary, our study reinforces the participation of genetic factors in the susceptibility to CPD, due to the association of less frequent alleles of the ILIB (rs1143634 T), IL6 (rs1800796 C) and CXCL8 (rs2227539 A) genes, which were found to be predictors 
of the disease. Highlight for the T (rs1143634) and C (rs1800796) alleles, which were associated with increased risk, when inferred individually and together. It is conjectured that the effect of mutant variants on gene regulation contributes to homeostatic imbalance through the autoimmune condition of recurrent (chronic) inflammation, which promotes conjunctive and bone loss of the tissues that support teeth. The impact of oral hygiene on the propensity and control of periodontitis is also noteworthy, since there was an association of less brushing with a tendency to affect the condition.

\section{ACKNOWLEGDMENTS}

To the professors, staff, and students of the Núcleo de Pesquisas Replicon from PUC Goiás for the help during the investigation by providing the equipment and space required for the development of the study. To the professors and students of the Laboratorio de Mutagênese of the UFG for the aid during the methodology, providing the equipment and space for the performed analyses. To the coordinator of the project, Prof. Renato Hannum, M.Sc., for this research initiative and other contributions. To the volunteers that took part in this study. To the Fundação de Amparo à Pesquisa do Estado de Goiás FAPEG, for funding this investigation.

\section{CONFLICTS OF INTEREST}

The authors declare no conflict of interest.

\section{REFERENCES}

Almeida RF, Pinho MM, Lima C, Faria I, et al. (2006). Associação entre doença periodontal e patologias sistémicas. Rev. Port. Med. Geral Fam. 22: 379-390.

Baker PJ and Roopenian DC (2002). Genetic susceptibility to chronic periodontal disease. Microbes Infect. 4(11): 11571167.

Barartabar Z, Nikzamir A, Sirati-Sabet M, Aghamohammadi E, et al. (2018). The relationship between 174 G/C and $572 \mathrm{G} / \mathrm{C}$ of IL-6 gene polymorphisms and susceptibility of celiac disease in the Iranian population. Gastroenterol. Rev. 13(4): 293-298.

Bellone E, Balestra P, Ribizzi G, et al. (2006). An abnormal mRNA produced by a novel PMP22 splice site mutation associated with HNPP. J. Neurol. Neuros Ps. 77(4): 538-540.

Bishu S, Koutroumpakis E, Mounzer R, Stello K, et al. (2018). The -251 A/T Polymorphism in the IL8 Promoter is a Risk Factor for Acute Pancreatitis. Pancreas. 47(1): 87-91.

Braosi APR, de Souza CM, Luczyszyn SM, Dirschnabel AJ, et al. (2012). Analysis of IL1 gene polymorphisms and transcript levels in periodontal and chronic kidney disease. Cytokine. 60(1): 76-82.

Brasil. Ministério da Saúde. Secretaria de Políticas de Saúde (2001). Departamento de Atenção Básica. Área Técnica de Saúde Bucal. Projeto SB 2000: condições de saúde bucal da população brasileira no ano 2000: manual do examinador/ Secretaria de políticas de Saúde, Departamento de Atenção Básica, Área Técnica de Saúde Bucal. Brasília: Ministério da Saúde.

Chatzopoulos G, Doufexi AE, Wolff L and Kouvatsi A (2018). Interleukin-6 and interleukin-10 gene polymorphisms and the risk of further periodontal disease progression. Braz. Oral Res. 32: e11.

Cui YX, Zhao H and Guo HQ (2016). Role of IL-8 rs4073 and rs2227306 polymorphisms in the development of primary gouty arthritis in a Chinese population. Genet. Mol. Res. 15(4): 1-7.

da Silva FRP, Vasconcelos ACCG, de Carvalho França LF, Di Lenardo D, et al. (2018). Association between the rs1143634 polymorphism in interleukin-1B and chronic periodontitis: Results from a meta-analysis composed by 54 case/control studies. Gene. 668: 97-106.

Devji T (2017). Moderate-quality evidence shows a strong association between inadequate oral hygiene and periodontitis. J. Am. Dent. Assoc. 148(11): 161. 
Ferrari SL, Ahn-Luong L, Garnero P, Humphries SE, et al. (2003). Two Promoter Polymorphisms Regulating Interleukin-6 Gene Expression Are Associated with Circulating Levels of C-Reactive Protein and Markers of Bone Resorption in Postmenopausal Women. J. Clin. Endocrinol. Metab. 88(1): 255-259.

Ferrari SL, Ahn-Luong L, Garnero P, Humphries SE and Greenspan SL (2003). Two Promoter Polymorphisms Regulating Interleukin-6 Gene Expression Are Associated with Circulating Levels of C-Reactive Protein and Markers of Bone Resorption in Postmenopausal Women. J. Clin. Endocrinol. Metab. 88(1): 255-259.

Finoti LS, Nepomuceno R, Pigossi SC, Corbi SC, et al. (2017). Association between interleukin-8 levels and chronic periodontal disease: A PRISMA-compliant systematic review and meta-analysis. Medicine. 96(22): e6932.

Flemmig TF (1999). Periodontitis. Ann. Periodontol. 4: 32-38.

Gore EA, Sanders JJ, Pandey JP, Palesch Y and Galbraith GMP (1998). Interleukin-1beta+3953 allele 2: association with disease status in adult periodontitis. J. Clin Periodontol. 25(10): 781-785.

Hajishengallis G (2015) Periodontitis: from microbial immune subversion to systemic inflammation. Nat. Rev. Immunol. 15(1): 30-44.

Holmstrup P, Damgaard C, Olsen I, Klinge B, et al. (2017). Comorbidity of periodontal disease: two sides of the same coin? An introduction for the clinician. J. Oral Microbiol. 9(1): 1-13.

Katneni UK, Liss A, Holcomb D, et al. (2019). Splicing dysregulation contributes to the pathogenicity of several F9 exonic point variants. Mol. Genet. Genomic Med. 7(8): 1-13.

Kaur N, Singh J and Reddy S (2019). Association of IL-8-251 A/T rs4073 and IL-10 rs1800872 -592C/A Polymorphisms and Coronary Artery Disease in North Indian Population. Biochem. Genet. 57(1): 129-146.

Laine ML, Crielaard W and Loos BG (2012). Genetic susceptibility to periodontitis. Periodontology 2000. 58(1): 37-68.

Lertpimonchai A, Rattanasiri S, Arj-Ong Vallibhakara S, Attia J, et al. (2017). The association between oral hygiene and periodontitis: a systematic review and meta-analysis. Int. Dent J. 67(6): 332-343.

Loos BG, John RP and Laine ML (2005). Identification of genetic risk factors for periodontitis and possible mechanisms of action. J. Clin. Periodontol. 32(SUPPL. 6): 159-179.

López NJ, Valenzuela CY and Jara L (2009). Interleukin-1 Gene Cluster Polymorphisms Associated With Periodontal Disease in Type 2 Diabetes. J. Periodontol. 80(10): 1590-1598.

Majumder P, Panda SK, Ghosh S and Dey SK (2019). Interleukin gene polymorphisms in chronic periodontitis: A casecontrol study in the Indian population. Arch Oral Biol. 101(March): 156-164.

Michalowicz BS (1994). Genetic and heritable risk factors in periodontal disease. J. Periodontology. 65: 479-88.

Moreira PR, De Sá AR, Xavier GM, Costa JE, et al. (2005). A functional interleukin-1 $\beta$ gene polymorphism is associated with chronic periodontitis in a sample of Brazilian individuals. J. Periodontal. Res. 40: 306-311.

National Center for Biotechnology Information. (2020) National Library of Medicine (US). SNP database. Avaliable at [https://www.ncbi.nlm.nih.gov/snp/rs1143634]. Accessed 13 June 2020.

Noh MK, Jung M, Kim SH, Lee SR, et al. (2013). Assessment of IL-6, IL-8 and TNF- $\alpha$ levels in the gingival tissue of patients with periodontitis. Exp. Ther. Med. 6(3): 847-851.

Paul AM, Victor DJ and Gana Prakash PS (2012). Role of Interleukin-8 in Periodontal Disease. Int. J. Clin. Dent. Sci. 3(2): 32-38.

Pociot F, Mølvig J, Wogensen L, Worsaae H, et al. (1992). A TaqI polymorphism in the human interleukin-1 beta (IL-1 beta) gene correlates with IL-1 beta secretion in vitro. Eur. J. Clin. Invest. 22(6): 396-402.

Qaddourah RH, Magdoud K, Saldanha FL, Mahmood, N, et al. (2014). IL-10 gene promoter and intron polymorphisms and changes in IL-10 secretion in women with idiopathic recurrent miscarriage. Hum. Reprod. 29(5): 1025-1034.

Ribeiro MSM, Pacheco RBA, Fischer RG and Macedo JMB (2016). Interaction of IL1B and IL1RN polymorphisms, smoking habit, gender, and ethnicity with aggressive and chronic periodontitis susceptibility. Contemp. Clin. Dent. 7(3): 349-356.

Rosales C and Uribe-Querol E (2017). Neutrophil Role in Periodontal Disease. In: Role of Neutrophils in Disease Pathogenesis. InTech. 83-88.

Sánchez GA, Miozza VA, Delgado A and Busch L (2013). Salivary IL-1 $\beta$ and PGE 2 as biomarkers of periodontal status, before and after periodontal treatment. J. Clin. Periodontol. 40(12): 1112-1117.

Santos JC, de Brito CA, Futata EA, Azor MH, et al. (2012). Up-regulation of chemokine C-C ligand 2 (CCL2) and C-XC chemokine 8 (CXCL8) expression by monocytes in chronic idiopathic urticaria. Clin. Exp. Immunol. 167(1): 129136.

Setty S, Bhat PR, Kulkarni B, Shivprakash H V, et al. (2018). Association of Interleukin-1 $\beta+3954$ ( Rs1143634 ) Gene Polymorphism in Periodontal Healthy and Chronic Periodontitis Patients Association of Interleukin- $1 \beta+3954$ ( Rs1143634 ) Gene Polymorphism in Periodontal Healthy and Chronic Periodontitis Patients. J. Dent. Med. Sci. 17: 58-63.

Shao M, Huang P, Cheng R and Hu T (2009). Interleukin-6 polymorphisms modify the risk of periodontitis:a systematic review and meta-analysis. J. Zhejiang Univ. Sci. B. 10(12): 920-927.

Shi D (2017). Interleukin-6-572C/G polymorphism is associated with the risk of chronic periodontitis. Biomed. Res. 28(15): 6637-6639. 
Song HK, Noh EM, Kim JM, You YO, et al. (2019). Reversine inhibits MMP-3, IL-6 and IL-8 expression through suppression of ROS and JNK/AP-1 activation in interleukin-1 $\beta$-stimulated human gingival fibroblasts. Arch Oral Biol. 108: 104530 .

Stabholz A, Soskolne WA and Shapira L (2010). Genetic and environmental risk factors for chronic periodontitis and aggressive periodontitis. Periodontol 2000. 53(90): 138-153.

Thi Tran HT, Takeshima Y, Surono A, Yagi M, Wada H and Matsuo M (2005). A G-to-A transition at the fifth position of intron-32 of the dystrophin gene inactivates a splice-donor site both in vivo and in vitro. Mol. Genet. Metab. 85(3): 213-219.

Trevilatto PC, de Souza Pardo AP, Scarel-Caminaga RM, de Brito RB, et al. (2011). Association of IL1 gene polymorphisms with chronic periodontitis in Brazilians. Arch Oral Biol. 56(1): 54-62.

Wang D, Guo Y, Wrighton SA, Cooke GE, et al. (2011). Intronic polymorphism in CYP3A4 affects hepatic expression and response to statin drugs. Pharmacogenomics J. 11(4): 274-286.

Wu Q, Zhou X, Huang D, Ji Y, et al. (2017). IL-6 enhances osteocyte-mediated osteoclastogenesis by promoting JAK2 and RANKL activity in vitro. Cell Physiol. Biochem. 41(4): 1360-1369.

Wu X, Offenbacher S, López NJ, et al. (2015). Association of interleukin-1 gene variations with moderate to severe chronic periodontitis in multiple ethnicities. J. Periodontal Res. 50(1): 52-61.

Xiao L, Yan Y, Xie C, Fan WH, et al. (2009). Association among interleukin-6 gene polymorphism, diabetes and periodontitis in a Chinese population. Oral Dis. 15(8): 547-553.

Yin WT, Pan YP and Lin L (2016). Association between IL-1 $\alpha$ rs17561 and IL-1 $\beta$ rs1143634 polymorphisms and periodontitis: A meta-analysis. Genet. Mol. Res. 15: gmr7325.

Zhang HY, Feng L, Wu H and Xie XD (2014). The association of IL-6 and IL-6R gene polymorphisms with chronic periodontitis in a Chinese population. Oral Dis. 20(1): 69-75.

Zhang N, Xu Y, Zhang B, Zhang T, et al. (2014). Analysis of Interleukin-8 Gene Variants Reveals Their Relative Importance as Genetic Susceptibility Factors for Chronic Periodontitis in the Han Population. PLoS One. 9(8): e104436. 